\title{
Apsolut uvijek ostaje apsolutni misterij
}

\author{
Anto Pavlović*, Hrvoje Vargić***
}

\begin{abstract}
Sažetak
Članak analizira filozofsku misao Rudolfa Brajičića iz perspektive utemeljenja i objektivnosti sintetičkih apriornih sudova, nastojeći istražiti mogućnost konstituiranja proširene metafizike, tj. metafizike koja proširuje znanje te ponovno otvora put racionalnoj teologiji. U svjetlu proširene metafizike, u drugom dijelu preispitujemo tradicionalne dokaze za Božje postojanje, upućujući također na neke nove vidike u dokazivanju. Dva prethodna koraka daju solidnu podlogu za osnovnu tezu članka, kojom se želi pokazati da, pošto ni nakon dokazane opstojnosti Apsoluta još nemamo pozitivan unutarnji uvid u Njegovu bit, u Njegov nutarnji život, Apsolut treba shvaćati kao apsolutan naravan misterij, a govor o Apsolutu kao govor o misteriju.

Ključne riječi: Brajičić, proširena metafizika, dokazivanje Božjeg postojanja, Apsolut, apsolutni misteriji
\end{abstract}

\section{Uvod}

Rudolf Brajičić SJ (1918. — 2007.), profesor, teolog i filozof, bio je izuzetno plodan teološki, a u kasnijoj fazi i filozofski pisac s približno 350 objavljenih bibliografskih jedinica. ${ }^{1}$ Brajičić je u domaćim znanstvenim krugovima poznat prvenstveno kao teolog, no njegov filozofski opus nije nipošto zanemariv. Ono što na poseban način karakterizira njegova filozofska promišljanja jest kontinuirano konfrontiranje s pojedinim tezama Kantove Kritike čistog uma, posebice s transcendentalnom estetikom. Iako to čini uglavnom s pozicija skolastičke filozofije, nerijetko u svojim razmišljanjima izražava neslaganje s tom istom filozofijom, što njegov rad čini dodatno zanimljivim i nadasve originalnim. To nesuglasje, a ponekad i kritika, naspram klasične filozofije ogleda se napose u pristupu dokazima za Božju opstojnost, kao i u samom poimanju Apsoluta (Boga). Tradicionalnoj

* Doc. dr. sc. Anto Pavlović, Filozofski fakultet Družbe Isusove, Zagreb. Adresa: Jordanovac 110, p.p. 169, 10001 Zagreb, Hrvatska. E-pošta: apavlovic2010@gmail.com

** Bacal. Hrvoje Vargić, Filozofski fakultet Družbe Isusove, Zagreb. Adresa: Jordanovac 110, p.p. 169, 10001 Zagreb, Hrvatska. E-pošta: hrvoje.vargic@gmail.com

1 Opširnije o Brajičiću i njegovim objavljenim radovima vidi u: M. Steiner, In memoriam — Rudolf Brajičić SJ (1918-2007), Obnovljeni život, 2007, 62, 1, 83-101. 
filozofiji ponajviše zamjera nedostatak rasprava o Apsolutu kao misteriju, čime ona »pokazuje stanovitu nemoć u hrvanju s modernim filozofijama ${ }^{2}{ }^{2}$ Stoga ce pozornost ovoga rada biti usmjerena upravo na problematiku poimanja Apsoluta (Boga) kao apsolutnog misterija, a zatim i na filozofske implikacije koje proizlaze iz takvog shvaćanja.

Da bi stvorili solidne pretpostavke koje ce nam omogućiti pristup toj centralnoj točki rada, smatramo da je najprije potrebno razmotriti Brajičićevo razumijevanje sintetičkih apriornih sudova, a potom na istom tragu utemeljenje proširene metafizike. Naime, te dvije točke, kao izvoran doprinos filozofiji o Bogu, predstavljaju temelj na kojem Brajičić preispituje i nadopunjava klasične dokaze za Božju opstojnost, te upućuje na neke nove vidike u dokazivanju. Te analize otvorit će put razlaganju naše temeljne teze, kojom želimo pokazati da se u filozofskom smislu najopravdanijim čini onaj pristup Apsolutu (Bogu) koji ga shvaća kao apsolutni naravni misterij. Naime, unatoč solidnim dokazima da razumskim putem možemo dokučiti postojanje Apsoluta, Njegov unutarnji život ostaje nam nedohvatljiv. Unatoč, dakle, nekim saznanjima dobivenim posrednim zaključivanjem, ipak, kada je riječ o Apsolutu (Bogu), moramo biti svjesni da je riječ o apsolutnom misteriju. Ta teza kao i filozofske implikacije koje sa sobom nosi bit će dodatno razjašnjene.

\section{Proširena metafizika kao temelj dokazivanja Božjeg postojanja}

\subsection{Transcendentalni odnosi jamac objektivnosti sintetičkih apriornih sudova}

Iako je problematika Brajičićeve proširene metafizike i njegova razumijevanja sintetičkih sudova a priori detaljnije obrađena na drugim mjestima, ${ }^{3}$ bit će vrijedno ovdje je ukratko preispitati kako bismo mogli analizirati njegov pristup dokazima za Božje postojanje, kao i govor o Bogu kao apsolutnom misteriju. Prihvaćajući Kantovu podjelu apriornih sudova na analitičke i sintetičke, suprotstavljajući se time skolasticima koji ih pokušavaju izjednačiti, sintetičke apriorne sudove ${ }^{4}$ Brajičić uzima kao temelj svojoj »proširenoj metafizici«. Riječ je o metafizici koja nadilazi tautologiju i proširuje znanje. ${ }^{5}$

Analizirajući Kantovo shvaćanje sintetičkih apriornih sudova, uočava njihove četiri vlastitosti: 6

2 R. Brajičić, Apsolut je apsolutan naravan misterij, Obnovljeni život, 1998, 53, 3, 248.

3 Vidi npr.: I. Macan, Recepcija I. Kanta u Rudolfa Brajičića (u daljnjem tekstu Recepcija), Obnovljeni život, 2004, 59, 4, 409-420. Ili: A. Pavlović, S. Štivić, Sintetički sudovi a priori i proširena metafizika kao temelj filozofije religije u misli Rudolfa Brajičića, Obnovljeni život, 2014, 69, 1, 53-70.

4 Sintetičke apriorne sudove Brajičić drugdje naziva i fizičkim analitičkim ili egzistentnim sudovima. Usp. R. Brajičić, Filozofski eksperiment: signifikantni i egzistentni vidici u filozofiji, Zagreb, 1996, 38-40. (U daljnjem tekstu Eksperiment).

5 R. Brajičić, Opravdanje čistog uma. U svjetlu transcendentalnih odnosa, Zagreb, 1988, str. 58. (U daljnjem tekstu Opravdanje).

6 Isto, str. 25. 
a) U sintetičkim sudovima a priori predikat nije zamišljen u pojmu subjekta.

b) Sintetički sudovi nisu analitički, nego nastaju na temelju sinteze, za čije konstituiranje moramo izići iz pojma subjekta.

c) Sintetički su sudovi oni u kojima se veza $A B$ zamišlja bez istovjetnosti.

d) Sintetički sudovi proširuju znanje.

Budući da Kant ne definira te sudove, Brajičić utvrđuje razliku između apsolutno apriornih sudova i transcendentalno relativnih apriornih sudova. Prvi izražavaju apsolutni sadržaj pojma te odgovaraju Kantovim analitičkim sudovima, a drugi su iskaz o transcendentalnim odnosima, tj. iskaz o odnosu apsolutnog subjekta prema nečemu drugomu na temelju subjektova apsolutnog ontičkog sadržaja. ${ }^{7}$

Brajičić se slaže s Kantom da u sintetičkim apriornim sudovima predikat nije zamišljen u apsolutnom pojmu subjekta, kao i da za znanje o pripadnosti predikata subjektu moramo izići iz danog pojma, tj. potrebno nam je nešto treće što ih sintetizira. No, tu se Kant i Brajičić razilaze: navedeni treći element za Kanta je sinteza mašte i jedinstvo transcendentalne apercepecije, dok je za Brajičića to element transcendentalnog odnosa.

Slaže se također s Kantom da između pojma subjekta i predikata ne postoji formalna istovjetnost kao u analitičkim sudovima, ali dodaje kako postoji materijalna istovjetnost. Iz tog razloga u sintetičkim apriornim sudovima predikat subjektu pridijeva nešto formalno novo, pa ih se prema sv. Tomi može nazvati »asekutivnim sudovima«, tj. onima u kojima se »predikat ne nalazi u subjektu, ali ga dohvaća snagom istoga subjekta.$^{8}$

Brajičić se slaže s Kantom i u tvrdnji kako sintetički apriorni sudovi proširuju metafizičku spoznaju, ali istovremeno čini znatan odmak od Kanta, braneći njihovu objektivnost. Temelj objektivnosti sintetičkih apriornih sudova i proširene metafizike nalazi se u transcendentalnim odnosima. "Sintetički sudovi nisu apriori, nisu ništa drugo nego sudovi u kojima je predikat transcendentalni odnos subjekta prema nečemu izvan njega. «9 Općenito, odnos se tu shvaća kao red (ordo) ili usmjerenost jednog bića prema drugomu; biti nekim načinom prema drugomu. U svakom odnosu razlikuju se subjekt, temelj i predmet odnosa. Transcendentalni odnosi sastoje se u tome da određena bića, na temelju svoje biti, imaju odnos prema drugomu biću. U tim odnosima apsolutna stvar snagom svoje biti ili same sebe upućena je na neko drugo bicee. Stoga, da bismo utvrdili istinitost i objektivnost sintetičkih apriornih sudova, potrebno je »uočavanje strukture transcendentalnog odnosa koji se u sudu izriče «. ${ }^{10}$

Međutim, tu se opravdano postavlja pitanje na koji način spoznajemo da predikat sadrži više od subjekta, na što Brajičić odgovara da to postižemo kontemplacijom subjekta i predikata te njihovih bitnih odnosa. Ivan Macan ne smatra taj

\footnotetext{
7 Usp. Isto, str. 26.

8 Opravdanje, str. 31.

9 Isto, str. 11.

10 Isto, str. 63.
} 
odgovor dovoljno uvjerljivim, iako ne nudi razloge za to. ${ }^{11}$ Brajičić i sam ističe kako »transcendentalni odnos ne mora biti odmah vidljiv i lako uočljiv «. ${ }^{12}$ Zato je potrebno njegove elemente svesti na jednostavnije oblike kako bi se lakše postigla evidencija. Sam odnos ne spoznajemo ni iz subjekta odjelito od predmeta, kao ni iz predmeta odjelito od subjekta ili iz samog osnova odnosa. Dakle, sam odnos je nešto više od svojih konstitutivnih dijelova, on je veza ili red među njima. Da bismo ga spoznali, trebamo dohvatiti bit njegovih konstitutivnih dijelova, te ga u povezanosti s njima promatrati (kontemplirati). Stoga zaključujemo da se sintetički sud a priori ne može deducirati ni iz čega, nego jedino otkriti neposredno kontemplacijom. Pojmu kontemplacije još ćemo se vratiti.

\subsection{Načelo uzročnosti kao transcendentalno odnosni sud}

Utvrđujući objektivnost sintetičkih apriornih sudova, Brajičić otvara mogućnost proširenoj metafizici, koja omogućuje uzlet u metafizičku stvarnost, otvarajući put spoznaji Božje egzistencije čistom umnom spekulacijom. Najprikladnijim primjerom sintetičkog suda a priori uzima načelo uzročnosti, te na njemu gradi prijelaz iz iskustvene $\mathrm{u}$ nadiskustvenu stvarnost.

Brajičić čini otklon od onih skolastičkih autora koji u načelu uzročnosti vide analitički sud (C. Nink, I. Zimmermann, F. Šanc), kao i od onih koji ga žele svesti na načelo identiteta ili protuslovlja (E. Coreth), smatrajući da ga svi oni pokušavaju izravno ili neizravno dokazati, što je neostvarivo. Također, Kantovu formulaciju načela uzročnosti - sve što biva ima svoj uzrok (biva ne znači vremenski početak) - smatra izvornijom od skolastičke — sve što kontingentno postoji ima uzrok - smatrajući je transcendentalno odnosnim sudom, koji je izraz odnosa subjekta postajanja prema predikatu od drugoga na temelju subjektova apsolutnog ontičkog sadržaja. Njezin bi najizvorniji oblik bio: »Sve što biva« ima odnos ovisnosti »od uzroka« na temelju apsolutnog ontičkog sadržaja bivanja. ${ }^{13}$

U tom sudu ostvaruju se sve četiri ranije spomenute vlastitosti sintetičkih apriornih sudova. Prvo, postajati i imati svoj uzrok nije formalno isto: subjekt i predikat nisu dakle formalno identični. Drugo, izvan subjekta i predikata mora postojati nešto treće što ih može sintetizirati, a to je pitanje izvora postajanja ili pojam uzroka. Treće, moram izići iz pojma subjekta da bih u suodnosu s njim promatrao predikat, a to je zadovoljeno jer su subjekt i predikat tu materijalno istovjetni, tj. isti je subjekt koji ima apsolutni sadržaj i koji ima suodnos izražen predikatom. I naposljetku, načelom uzročnosti nadilazimo tautologiju i stječemo novu spoznaju: sve što biva ima svoj uzrok ili od drugoga biva. Time su zadovoljeni svi uvjeti sintetičke apriornosti načela uzročnosti.

Kako je rečeno ranije, taj sud se ne može dokazivati dedukcijom, nego svođenjem svih elemenata suda na jednostavnije oblike kako bismo njihov odnos do-

13 Isto, str. 59. 
veli do što većeg stupnja evidencije i time njegovu istinitost učinili dostupnijom uvidu (kontemplaciji). Kada je riječ o načelu uzročnosti to konkretno znači: ${ }^{14}$

a) Jednostavan oblik načela uzročnosti: Sve što biva ima svoj uzrok.

b) Izričitija formulacija transcendentalnog suodnosa: Sve što biva na temelju samog bivanja ovisi o uzroku (u uzroku mu je uvjet mogućnosti bivanja).

c) Svođenje elemenata na jednostavnije oblike: sve što biva $\rightarrow$ sve što prima bitak (def.), na temelju samog bivanja $\rightarrow$ na temelju samog primanja bit$\mathrm{ka}$, ovisi od uzroka $\rightarrow$ ovisi od davaoca bitka (def. uzroka).

d) Načelo uzročnosti složeno prema jednostavnijim oblicima iz točke c: Sve što prima bitak, ovisi od davaoca tog bitka na temelju samog primanja, ili: sve što prima bitak, ovisi od davaoca tog bitka.

To bi, dakle, bio put do evidencije načela uzročnosti. A njegova se istinitost sada može utvrđivati kontemplacijom, koja je svojevrsno umno uranjanje u evidentirane sastavnice. To je ujedno i krajnja granica do koje se može ići.

Ipak, moramo ovdje ustvrditi da je Brajičić ostavio poprilično nerazjašnjenim, kako put dolaska do mogućnosti kontempliranja veze (suodnosa) između subjekta i predikata, tako i sam pojam kontemplacije i njezine uloge u tom cijelom procesu. Naime, ako se kontemplacija može prispodobiti nekakvomu umnomu ili intuitivnomu (intus legere) duhovnomu dinamizmu, kojemu, kako se iz konteksta čini, Brajičić nije previše sklon, ne bi li onda ona trebala biti prvi korak, koji bi bio uvjet mogućnosti naknadnog razumskog (raz-um-ijevanje) raščlanjivanja suda na jednostavnije sastavnice? Ne bi li se najprije kontemplacijom trebala postići evidencija u složenost suda od jednostavnijih elemenata, koju bi zatim trebala slijediti razumska raščlamba tih jednostavnijih elemenata? U svakom slučaju, budući da filozofska kontemplacija nije dio svakodnevnog, lako provjerljivog iskustva, bilo bi korisno da je Brajičić na konkretniji način izložio i pojasnio samu verifikaciju tog spoznajnog procesa. Cijeli taj put bio bi razumljiviji da je dao neke smjernice kojima bi pomogao doći do toga iskustva kontemplacije, slično kao što je to učinio razlaganjem sintetičkih apriornih sudova na jednostavnije sastavnice, kako bi nužna veza između subjekta i predikata bila očiglednija.

\section{Dovršenje tradicionalnih dokaza i neki novi vidici u dokazivanju}

Nakon što se, na temelju razmatranja transcendentalnih odnosa, utvrdila objektivna vrijednost načela uzročnosti kao sintetičkog suda a priori, stvorene su pretpostavke za jednu novu i originalnu perspektivu pristupa dokazima za Božju opstojnost na koju Brajičić upućuje:

Dokaz za Božju opstojnost pitanje je eminentno metafizičke naravi, a pri tome mislim na proširenu metafiziku, u kojoj se iz jednog pojma, stečena iz iskustva, može snagom transcendentalnog odnošaja doći do novih spoznaja. Od svih novih spoznaja 
do kojih tako možemo doći Bog je najuzvišenija, jer kao Biće koje nadilazi vremenitost i prostornost, kao i svaku ograničenost, veličina je od koje se veća ne može zamisliti. Ta veličina zauzima mjesto Apsolutnog bića, prema kojemu ostale veličine zauzimaju položaj podređenosti i ovisnosti. ${ }^{15}$

Predstoji nam sada iz te perspektive razmotriti tradicionalne dokaze (ontološki i kozmološki), te preispitati neke nove pristupe dokazivanju.

\subsection{Ontološki dokaz: od metafizičkih realiteta prema iskustvenoj činjenici}

Anzelmov dokaz Brajičić donosi u ovoj formulaciji: »Bog kao najsavršenije biće je u zbilji, jer kada najsavršenije biće ne bi bivstvovalo u zbilji, ne bi bilo najsavršenije, budući je bivstvovati u zbilji savršenije od bivstovanja samo u mislima. «16 Dakle, Bog kao najsavršenije biće postoji u zbilji je istina znana sama po sebi, tj. analitički sud.

U suglasju s mnogim filozofima koji su detaljno proučavali Anzelmov dokaz te ga odbacili (Toma A. F. Copleston, L. Billot, P. Descoqs, M. Rast, V. Keilbach, J. M. Dalmau C. Fabro i dr.), i Brajičić mu ne priznaje dokaznu snagu, unatoč činjenici da su ga kroz povijest mnogi prihvaćali (A. Haleški, Bonaventura, Egidije Rimski, Duns Scot, Descartes, Lebniz). Temeljni razlog za odbacivanje tog argumenta je u činjenici da, prije nego što se dokaže Božja opstojnost, mi ne znamo je li pojam najsavršenije biće (nužno biće) — što je polazišna točka dokaza - pozitivno unutarnje moguć, iako u njemu ne nalazimo nikakvo protuslovlje. Razlog zašto nemamo pozitivnu unutarnju mogućnost pojma najsavršenijeg bića jest taj što nemamo vlastit pojam o Božjoj bîti, koji se stječe neposrednim zorom (visio) Boga. Budući, dakle, da nemamo pozitivan uvid u unutarnju mogućnost pojma najsavršenijeg ili nužnog bića, ne možemo iz tog pojma zaključiti da Bog postoji. Tu treba naznačiti da i poslije aposteriornih dokaza, Bog nam ostaje skriven s obzirom na svoju bît, iz čega uviđamo da filozofski ispravan pristup Apsolutu (Bogu), kao nužnomu biću, može biti jedino onaj koji ga shvaća kao apsolutni naravni misterij. Tomu uvidu vratit ćemo se kasnije.

No, Brajičić tu nudi jedan drugačiji pristup Anzelmovu dokazu: pokušat će pokazati realnost pojma »najvećeg (najuzvišenijeg) bića « da bi iz njega zaključio o njegovoj opstojnosti u zbilji. Dokaz time dobiva jednu novu perspektivu, u kojoj ne bi bilo težište isključivo na apriornosti, nego bi tu riječ bila o dokazivanju silaznim putem (via descenti): od metafizičkih realiteta prema iskustvenoj činjenici, umjesto suprotno, tj. uzlaznim putem (via ascenti). ${ }^{17}$

Promotrimo o čemu je tu riječ.

Kao i Anzelmo, Brajičić polazi od pojma apsolutnog, a ne relativnog, najvećeg mogućeg bića. Taj pojam je prema Brajičiću realan, jer njime zamišljamo ono što je unutarnje moguće. Ako bi tko poricao tu realnost, upao bi u protuslovlje

15 Opravdanje. str. 115.

16 R. Brajičić, Govor o Apsolutu je govor o misteriju (u daljnjem tekstu Govor), Zagreb, 2000, str. 11.

17 R. Brajičić, I ontološki i kozmološki dokaz za Božju opstojnost treba dovesti do kraja, Obnovljeni život, 1994, 49, 4, str. 409. 
tvrdeći da apsolutno najveće moguće biće je nemoguće biće. A budući da je pojam apsolutnog najvećeg mogućeg bića realan, to biće mora biti ostvareno, a to je moguće jedino po sebi, a ne po drugome; učinak ne može biti veći od uzroka. Ono što ima razlog postojanja u sebi, to mora postojati u zbilji. Dakle, tu se ostvarljivost pojma najuzvišenijeg mogućeg bića ne izvodi iz samog pojma, nego iz stvarne (zbiljske) realnosti tog pojma. ${ }^{18}$

Stvar će biti jasnija ako razmotrimo pozadinu problema, koja pokazuje u čemu je zapravo temelj neslaganja Brajičića s Kantom. Brajičić se naime pita je li apsolutno najveća savršenost moguća prethodno od zbiljske egzistencije ili je ona unutarnje moguća posljedično od egzistencije, tj. jer postoji, zato je unutarnje moguća. Kant se priklanja prvomu, u čemu Brajičić vidi problem, naznačujući da, kad bi to bilo tako, onda ona ne bi bila apsolutno najveća moguća savršenost, nego samo relativna, te dodaje da takva mogućnost postojanja nužno pretpostavlja zbilju na kojoj se temelji. U tom smislu prigovara Kantu da zanemaruje činjenicu da se unutarnja mogućnost stvari ne da misliti bez odnosa na opstojnost: što nije egzistibilno, nije unutarnje moguće. Te zaključuje: »Bog je moguć jer postoji, ne obratno. «19

$\mathrm{Na}$ istoj podlozi Brajičić kritizira i Kantovo osporavanje realnosti pojma apsolutno nužnog bića. Kant tvrdi da »ako ukinemo opstojnost apsolutno-nužnog bića, onda ukidamo samu stvar sa svim njenim predikatima, te time ne upadamo u nikakvo protuslovlje, jer nema ničega čemu bi se protuslovilo, ni izvana (jer nužno biće nije izvana nužno), ni iznutra (jer se ukidanjem same stvari ukida i sve unutarnje) «. ${ }^{20}$ Brajičić pak, čini se poprilično razložno, smatra da je nužna opstojnost, zapravo sva opstojnost: ako bi bila samo dio, ostatak bi bio kontingentan ili ništa, a tada bi i onaj dio uzet od ostatka bio iste ontološke konzistencije. Ako, dakle, postoje kontingentna bića, ona mogu postojati samo u ovisnosti o nužnom biću. Stoga, ako Kant želi ukinuti nužno biće, mora ukinuti sva ne-nužna bića koja su o nužnom biću apsolutno ovisna, a to bi bilo u potpunoj opreci s iskustvom.

No, tu se pokazuje jedna druga stvar koja nije posve jasna u tom Brajičićevu razmišljanju: kako u toj fazi (via descenti), koja je još uvijek pod jakim prizvukom transcendentalnosti a time i apriornosti, iz iskustva kontingentnih bića znamo da ona nužno ovise o apsolutnom biću? Zanimljivo je rješenje koje Brajičić nudi na ovo pitanje. On smatra da to doznajemo iz kozmološkog dokaza, te predlaže da za dokazivanje Božje opstojnosti treba krenuti deduktivnim putem (via descenti), tj. iz realnosti samih pojmova, a zatim potvrdu tih izvoda tražiti u iskustvu. Specifičnost Brajičićeva pristupa ogleda se upravo u tome što on apriorni put dokazivanja smatra pouzdanijim od aposteriornog, ali istovremeno smatra da apriorno dokazivanje, da bi bilo kompletirano i time zadobilo dokaznu snagu, mora izvršiti priziv na ono aposteriorno, kozmološko. ${ }^{21}$

18 Više o tome vidi: Isto, str. 409-418.

19 Isto, str. 411.

20 I. Kant, Kritika čistog uma, (prev. V. Sonnenfeld), Zagreb, 1984, str. 274.

21 Usp. R. Brajičić, I ontološki i kozmološki dokaz za Božju opstojnost treba dovesti do kraja, str. 415. 


\subsection{Kozmološki dokaz: ne žnužno biće općenito', nego kao uzrok kontingentnih bića}

U promišljanju kozmološkog dokaza Brajičić polazi od njegove dvije formulacije. Prva je Kantova: »Ako nešto egzistira, onda mora egzistirati i apsolutno nužno biće. U najmanju ruku egzistiram ja; dakle, egzistira neko apsolutno nužno biće. «22 Druga je skolastička, koju smatra sadržajnijom i prihvatljivijom: »Postoji kontingentno biće, koje nema dovoljnog razloga svoje opstojnosti u svojoj biti. Dakle, taj se razlog mora nalaziti u nužnom biću kao u njegovom uzroku. Postoji, dakle, nužno biće uzrok kontingentnih bića. «²3 Iz same formulacije jasno je zašto mu je druga prihvatljivija: tu se polazi od iskustva kontingentnih bića te se pomoću načela uzročnosti uzdiže do postojanja nužnog bića, a dokaz ne završava tvrdnjom o postojanju nužnog bića općenito, nego nužnog bića kao uzroka kontingentnih bića.

Kako bi nasuprot Kantu utemeljio kozmološki dokaz, Brajičić mora odgovoriti na njegova tri osnovna prigovora. ${ }^{24}$ Prije svega s tvrdnjom kako skolastici, pošto su dokazali na temelju iskustva da postoji nužno biće, žure proniknuti narav, tj. savršenosti tog bića. No, ako promotrimo klasične dokaze (primjerice Tomine putove), prilično je jasno da se skolastici u samom dokazu zadovoljavaju zaključkom da nužno biće stvarno postoji, a tek u drugom koraku nastoje otkrivati njegove savršenosti. Ipak, imajući u vidu taj prigovor, Brajičić tvrdi kako i kozmološki dokaz treba dovesti do kraja.

Kant nadalje smatra kako se kozmološki dokaz služi iskustvom samo kako bi napravio jedan korak; da bi došao do opstojnosti nužnog bića uopće. No, da bi shvatio kakve vlastitosti ima to biće, to mu iskustvom potvrđeno načelo (načelo uzročnosti, op.) ne može reći. ${ }^{25}$ Razvidno je da Brajičić ne postupa tako. Njegov cilj nije opstojnost nužnog bića uopće, nego nužno biće kao uzrok kontingentnih bića. Čini se ipak kako je problem, kao i u prvom slučaju, u samoj Kantovoj formulaciji kozmološkog dokaza. Brajičić stoga ne pravi samo jedan korak, nego upravo različitost tog prvog koraka u odnosu na Kanta omogućuje mu još jedan vrlo važan, koji ide od iskustvene stvarnosti do savršenosti nužnog bića, kao njegovih vlastitosti; i taj korak izvodi iz načela uzročnosti. Vlastitost načela uzročnosti, koja pomaže otkriti savršenosti nužnog bića, očituje se pak u načelu da »što god se nalazi u učinku, treba biti i u uzroku«, te je stoga logično zaključiti da nužno biće ima sve savršenosti koje su i u kontingentnim bićima, naravno, intenzitetom primjerenim nužnom biću.

Treći i ključni Kantov prigovor proizlazi iz činjenice da načelo uzročnosti gleda isključivo u okviru osjetnog iskustva, odričući mu bilo kakvu metafizičnost, što posljedično znači da na temelju njega nemamo pravo zaključivati na savršenosti nužnog bića. No, tu se opravdano postavlja pitanje: kako smo onda empirijskim

22 I. Kant, Kritika čistog uma, str. 278.

23 R. Brajičić, I ontološki i kozmološki dokaz za Božju opstojnost treba dovesti do kraja, str. 419.

24 Usp. Isto, str. 419-424.

25 Usp. I. Kant, Kritika čistog uma, str. 278-279. 
načelom mogli doći do samog postojanja nadempirijskog nužnog bića? Kant će se tu jednostavno ograditi tvrdeći da smo dokazali postojanje, ali na način datum (sed) non concessum. Nedvojbeno je, dakle, da Kant, ne dopuštajući, bez pravog objašnjenja, korištenje navedenog načela u sljedećim koracima, očituje svojevrsnu nedosljednost. Brajičić to pak smatra sasvim dovoljnim, jer kada smo jednom na metafizičkoj razini prihvatili načelo uzročnosti na način datum (sed) non concessum, onda je legitimno koristiti ga, ne samo u prvom koraku dokazivanja opstojnosti nužnog bića, nego i u kasnijim koracima, koji uostalom, posljedično proizlaze iz prvog. Na tom tragu Brajičić opravdava govor o savršenostima nužnog bića na temelju načela uzročnosti na način datum (sed) non concessum, i na taj način dovršava kozmološki dokaz zaključujući: »mi smo dokazali da postoji nužno biće i da su u njemu sve savršenosti kontingentnih bića na eminentan način kao u njihovu uzroku«. ${ }^{26}$

\subsection{Proširena metafizika i novi vidici dokazivanja Božjeg postojanja}

U prethodnim analizama razmatrali smo Brajičićevu zamisao da na temelju proširene metafizike promišlja tradicionalne dokaze za Božju opstojnost. Na istim pretpostavkama Brajičić ide korak dalje, upućujući na neke nove vidike i mogućnosti u dokazivanju, čime zaista daje svojevrstan originalan doprinos filozofiji o Bogu. Te nove pokušaje uobličuje u pet puteva, aludirajući na Tominih pet puteva, dajući im predznak apriornosti. ${ }^{27}$ Ukratko ćemo ih ispitati i na kraju dati vlastitu prosudbu.

Prvi pokušaj temelji na pojmu najvećeg mogućeg bića, o kojem smo već prethodno govorili. Tu ne polazi od pojma »najvećeg bića koje se dade zamisliti«, nego od pojma »bića apsolutno najveće moguće bîti« ${ }^{28}$ Taj pojam ne uključuje samo unutarnju mogućnost, nego i mogućnost njegova stvarnog ozbiljenja. Tko bi ga nijekao upao bi u protuslovlje, tvrdeći da biće apsolutno najveće moguće bîti nije moguće. Pitajući se o izvanjskom ostvarenju tog pojma, uviđamo da je to moguće ili od drugoga ili po sebi. Jasno je da se ne može ostvariti od drugoga, jer učinak ne nadilazi uzrok, pa je nužno da se ostvari po sebi. Zaključujemo stoga da se biće, koje razlog svoje opstojnosti ima u sebi, mora nalaziti u zbilji.

Drugi put počiva na specifičnosti pojma bića. Opći pojmovi su indiferentni spram ostvarivanja u ovom ili onom konkretnom subjektu, i ne moraju se u njima nužno ostvariti, iznimka je pojam bića, koji se mora uvijek nužno ostvariti. Taj pojam je realan jer ga i iskustvo potvrđuje, a negiranje njegova nužnog ostvarenja vodilo bi u protuslovlje. Na prigovor upućen već Parmenidu, kako bi u tom slučaju sve što postoji moralo nužno postojati, Brajičić odgovara da biće promatrano u sebi, u svom formalnom sadržaju, ne sadrži nužno egzistenciju u zbilji, pa ga zato promatramo u odnosnom smislu. Činjenica je dakle da postoje bića koja su obilježena nenužnošću, ali ne mogu sva bića biti takva. Upravo ta

26 R. Brajičić, I ontološki i kozmološki dokaz za Božju opstojnost treba dovesti do kraja, str. 423.

27 Usp. Eksperiment, str. 47.

28 Usp. Isto, str. 47-50. 
činjenica postojanja nenužnih bića upućuje na zaključak o nužnosti postojanja nekog Apsolutnog bića.

Treći put polazi iz bića kao mogućnosti opstojnosti. Biće znači realnu mogućnost postojanja, a ona je kao takva vječna i nužna; nikad nije bilo da je nije bilo i nemoguće je da je ne bude. No, nedvojbeno je da je mogućnost realna samo u odnosu na zbiljnost, a vječna je i nužna samo ako se odnosi na vječnu i nužnu zbiljnost. Vječna i nužna zbiljnost je dakle realna. ${ }^{29}$

Četvrti put izvodi iz nužnosti postojanja nečega. Na pitanje zašto postoji nešto a ne ništa, Brajičić odgovara: jer nešto mora nužno postojati. Kad neko biće ne bi nužno i po sebi postojalo, nešto ne bi nikad postojalo, jer ne bi ga imao tko ostvariti. Nešto ipak postoji... ${ }^{30}$

Peti put polazi od općih pojmova. Uzimajući sve opće pojmove osim pojma bića, uključujući i pojam nešto — svi opći pojmovi su dionici tog pojma — ako se odnosi na materijalne stvari, vidimo da se oni ne mogu ostvariti po sebi; indiferentni su spram ostvarivanja u ovom ili onom konkretnom subjektu. Unutarnja nemogućnost ostvarenja po sebi pokazuje se kao vlastitost općih pojmova. S druge pak strane postavlja se pitanje: pojmovi biti po sebi, biti nužno, biti jedno u jednome, jesu li realni? Iako ih nemamo u neposrednom iskustvu, uočavamo da se pojavljuju uz opće pojmove i to u odnosu kontrarnosti sine medio (sve što jest; ili je ab alio ili $a$ se). S obzirom da su opći pojmovi realni, smijemo zaključiti da su i njima kontrarni pojmovi realni: kontrarnost je uvijek neki suodnos, koji, ako je $\mathrm{s}$ jedne strane stvaran, s druge je bar objektivno pojmovan. Dakle, biti po sebi, biti nužno, biti jedno u jednome jesu realni pojmovi te su vlastitosti onoga bića koje se nužno ostvaruje tako da mu svaka neostvarenost protuslovi; ostvaruje se $a$ se, kao potpuno Jedno, kao Apsolut (Bog). ${ }^{31}$

Ovdje je potrebno posebno osvrnuti se kratko na predznak apriornosti koji Brajičić daje svojim putevima. Kad u drugom putu tvrdi da je pojam bića realan, jer ga imamo iz iskustva, ili kad u četvrtom tvrdi da nešto ipak postoji, postavlja se pitanje: implicira li to da dotične uvide dobivamo aposteriorno? Tvrdeći da nešto ipak postoji, ne zaključujemo li to, bar u prvom koraku, iskustvom, tj. aposteriorno? Isto se pitanje nameće i kad Brajičić tvrdi da je pojam bića realan jer ga iskustvo potvrđuje. Zamjećujemo da u članku I ontološki i kozmološki dokaz treba dovesti do kraja jasnije nego u članku Filozofski eksperiment ističe važnost aposteriornog pristupa, koji dopunjuje apriorni. To nas navodi na zaključak da apriornost Brajičićeva pristupa dokazima za Božju opstojnost nužno potrebuje iskustvenu potvrdu, te da su neodvojivi dio istog procesa. No, time ipak nije riješena dvojba vezana uz aspekt apriornosti Brajičićevih puteva. Ostaje pitanje: je li uistinu prvi korak u njegovu dokazivanju čisti pojam, neovisan o iskustvu? Naime, i taj čisti pojam, prije nego se nađe u umu, da bi ga se moglo analitički ili

29 Usp. Isto, str. 53.

30 Usp. Isto

31 Usp. Isto, str. 53-58. Ili: R. Brajičić, Opći pojmovi slavu Božju kazuju, Obnovljeni život, 1996, 51, 3, 191-196. 
sintetički razlagati, morao je tamo nekako doći, a tu je teško zaobići iskustvo, jer Brajičić nije pobornik ideje o urođenim pojmovima, niti apriornih transcendentalnih elemenata spoznaje na Kantov način. Stoga se ipak čini da u Brajičićevu dokazivanju iskustvo nije samo naknadno polje verifikacije apriornih puteva, nego i njihov pretkorak.

\section{Klasična filozofija pokazuje nedovoljnu svijest o Apsolutu kao misteriju}

Iz dosadašnjih analiza pokazalo se očitim da je pitanje Boga, Apsoluta, ili kako on to naziva »apsolutologija «, za Brajičića ujedno i centralno pitanje filozofije uopće. U tom smislu i postavlja tezu da se »sve metafizike razlikuju upravo prema tome kakav stav zauzimaju prema Bogu kao Apsolutnom biću i kako ga zamišljaju. Ostale razlike nemaju takvo značenje kao ova. «32 Upravo se na pitanju shvaćanja Apsoluta na najbolji način ogleda originalnost Brajičićeve filozofske misli o Bogu. Tu Brajičić nastoji ukazati na određene manjkavosti tradicionalne filozofije u poimanju Boga, koje su je u mnogome učinile neučinkovitom u hrvanju s novim izazovima.

\subsection{Misterij Apsoluta jest neshvatljiv, ali on sam ne sastoji se u neshvatljivosti}

Prethodno smo utvrdili da prije nego dokažemo opstojnost Boga kao najsavršenijeg i nužnog bića, nemamo pozitivan uvid u unutarnju mogućnost tog pojma (u njegovu bît). To se ne mijenja ni kada iskustvo potvrdi da je taj pojam moguć: »Znamo za Apsolutovu unutarnju mogućnost iz dokaza za njegovu opstojnost, koji nam govore da nužno apsolutno biće mora opstojati po sebi, ali mi to biće ne vidimo, niti ga možemo vidjeti, pa nam sama njegova unutarnja mogućnost ostaje skrivena. «33 Naime, kad bi po dokazima Božja bît postala transparentna našemu razumu, onda bi snagom tog istog razuma bilo moguće dohvatiti nutarnji Božji život, odnosno dokučiti misterij presvetog Trojstva, što je naravno nemoguće. Stoga smatramo da je ispravno ustvrditi da je u filozofskom smislu najprimjereniji onaj pristup Apsolutu (Bogu) koji shvaća i odnosi se prema Njemu kao prema apsolutnomu naravnomu misteriju. Apsolutni misterij je, dakle, onaj pojam čiju unutrašnju mogućnost ne možemo neposredno pozitivno spoznati ni nakon saznanja da postoji u zbilji. Dokazima možemo doći do točke u kojoj se jasno očituje da je taj složeni pojam spojiv, da u njemu nema protuslovlja, ali učiniti ga »prozirnim « našemu razumu nije moguće. Stoga Brajičić svu apsolutologiju (filozofiju o Bogu) naziva govorom o misteriju: sve naše tvrdnje o Bogu kao aktualizaciji svake savršenosti počivaju na misteriju, i kao takve ne mogu nam postati po sebi razumljive istine (propositiones per se notae).$^{34}$

32 Opravdanje, str. 114.

33 Govor, str. 17.

34 Usp. Isto, str. 18. 
Osvijetlimo pojedine aspekte upravo iznesenih tvrdnji.

Iz gore rečenog razabiremo da Brajičić promatra Misteriji pod dva vidika: a) primarni misterij — sāmo nužno biće; b) sekundarni misterij — savršenosti nužnog bića. Na temelju toga se razumijeva i tvrdnja da se »svi slažu da je Apsolut (Bog) Misterij, neshvatljivo otajstvo, ali pri tome ponajčešće pomišljaju na njegovu beskonačnost, sveznanje, svemoć, dakle, na njegove atribute, a lako zaboravljaju na njegovu $b \hat{t} t$ tj. da je sama opstojnost (ipsum Esse) prvo i temeljno otajstvo iz kojeg izvire sve na njemu i izvan njega otajstveno.«35 Treba dakle uvijek imati u vidu da su svi Božji atributi pojedinačno i zajedno »dio« apsolutnog misterija Apsolutnog bića.

Zaboravimo li na Apsolut kao apsolutan misterij, mi ćemo se u svojim filozofskim razmišljanjima i u svojim teološkim spekulacijama rado zaustavljati na Božjoj neshvatljivosti, ne misleći da neshvatljivošću ne izričemo Božji misterij ukoliko je misterij. [...] Misterij Apsoluta jest, naime, neshvatljiv, ali se ne sastoji u neshvatljivosti. ${ }^{36}$

Što iz gore iznesenih postavki zaključujemo?

Uviđamo prije svega da pojam nužnog bića, shvaćen kao apsolutni misterij, dovodi u istu nedoumicu i filozofiju (općenito) i spekulativnu teologiju (teološku filozofiju): a) Apsolutan misterij jednako je nazočan u objema; b) obje su iskustveno neprovjerljive. Kao izlaz, Brajičić nudi jednu vrlo zanimljivu ideju. Naime, on, kao i nekolicina neoskolastika (K. Rahner, E. Coreth, J. de Finance i dr.) u teologiji, ili još preciznije u Objavi, vidi logično dovršenje svih filozofskih stremljenja, a posebice onih koja se odnose na pitanje Apsoluta (Boga). Stoga, napose kršćanskim filozofima, sugerira da taj put i stvarno uzmu u ozbiljno razmatranje te da koriste njegove blagodati. ${ }^{37}$

Očito je, nadalje, da se uvođenjem Apsolutnog misterija u filozofiju ozbiljno dovode u pitanje određene racionalističke struje, koje, u različitim formama, zagovaraju mogućnost pozitivnog logičkog uvida u unutarnju mogućnost bitka. Po sličnoj osnovi prigovor ide i onim filozofijama, nastalim na platonsko-augustinskoj tradiciji, koje zastupaju neku vrstu gledanja (intuicije) Bitka, te ne posvećuju dovoljnu pozornost Apsolutu kao apsolutnomu misteriju.

Utvrđujemo naposljetku da se nužno biće ili biće a se (Misterij) ni na koji način ne smije niti može poistovjetiti s apsurdom. Na pojmovnoj razini apsurd se javlja tamo gdje spojimo dva pojma koji su nespojivi (primjerice četverokutna kružnica), što je analitički apsurd. Osim toga može se također govoriti i o sintetičkim inačicama apsurda (primjerice apsolutno najkraća kriva crta). Tvrdeći, dakle, da nužno biće nije apsurd, tvrdimo da njegov pojam nije sastavljen od nespojivih (protuslovnih) pojmova. Pokazali smo da u misteriju nema protuslovlja, dok je $\mathrm{u}$ apsurdu protuslovlje očito. Treba također napomenuti da to ima enormne impli-

35 FiF, str. 140. Govoreći o Misteriju, Brajičić koristi pojmove i otajstvo i tajna. Smatramo da je tu primjerenije reći da je Misterij otajstvena, nego tajanstvena ili tajnovita stvarnost, stoga ćemo koristiti taj pojam.

36 Govor, str. 27.

37 Usp. R. Brajičić, Proširenje filozofije na područje Objave, Obnovljeni život, 2000, 55, 1, 101-105. 
kacije na ljudsku spoznaju. Smislenost je pretpostavka i uvjet mogućnosti svake naše spoznaje: sve što nije apsurdno, spoznatljivo je. Naravno, kada je riječ o nužnom biću, o Misteriju, ta spoznaja nije izravna i neposredna, nego analogna, tj. posredna: »znati i ujedno ne znati — to je dijalektika misterija «.38

\subsection{Tragom dijalektike 'znati i ujedno ne znati'}

Dijalektika kojom se propinjemo do Misterija, a koja se izriče u naizgled paradoksalnom iskazu znati $i$ ujedno ne znati, upućuje na opsežnu temu analogije, tj. analogne spoznaje i analognog govora o Misteriju (Bogu). U ovom radu nije nam cilj, niti je moguće, otvarati to veliko područje, nego, pretpostavljajući ga i koristeći njegove blagodati, nastojat ćemo iznijeti na vidjelo još neke vidike koji će pridonijeti boljem rasvjetljavanju samog pojma Misterija.

Apsolut (Bog) je misterij prije svega zbog toga što u sebi sadrži, tj. jer je preobilje bitka, punina bitka. Dok realnost svih drugih bića je u tome da sve što jesu i što imaju, jesu i imaju samo zato što primiše ili još bolje primaju od Njegove punine — smatramo da je to sadržajniji i životniji izraz od participacije. Pokazujući prethodno da je Misteriji (Bog) jedino biće u apsolutnom smislu, jasno smo ga odvojili od svih drugih bića, te se stoga pojam biće $u$ apsolutnom smislu može uzeti za adekvatan pojam metafizičke biti Prvog bića, tj. Božje biti. Postoji, dakle, samo jedno biće u apsolutnom smislu, dok su sva druga bića u odnosu prema njemu kao metafizičkomu temelju. No, pošto je nužno postojanje vlastitost Prvog bića, tu se neizostavno mora naglasiti da pojam tog Bića ima participacijsko (glagolsko pridjevno), a nikako nominalno (imenično) značenje. Apsolut je, dakle, prvotno Apsolutni bitak, a ne Apsolutna bît konotirajući apsolutni bitak, prvotno je Apsolutni čin (actus), a ne Apsolutna bît. Pa kad ga nazivamo i bićem, to govorimo uvijek u analognom smislu, jer i pojam bića nije pravi izraz za njega: On naprosto Jest, jest punina od koje svi mi primismo...

Jasno je, dakle, da su bića s bitkom na mjeru primjerenija našemu shvaćanju, dok nam beskonačnost (punina) samog Bitka uvijek izmiče. Stoga tu smatramo vrlo razložnim Brajičićevo parafraziranje poznatog Wittgensteinova citata, čime potvrđuje gore rečeno, ali i otvara mogućnost da ipak ima neki smisao ono što se kaže o Onome koji je iskonski izvor i temelj svake smislenosti:

O Apsolutnom misteriju se ne može govoriti na način da se ima neposredan pozitivan uvid u unutrašnju mogućnost onoga što se govori, pa zato u tom smislu o Apsolutnom misteriju zaista treba šutjeti. Silentium Tibi laus. No, može se govoriti o tome, u čemu se Apsolutni misterij sastoji, što njim izričemo, koju realnost s njim tvrdimo, premda o njoj nemamo neposredan uvid. ${ }^{39}$

Na tom tragu možemo reći da Apsolut (Punina) ima svoje atribute koji predstavljaju ključ po kojem se analoški uspinjemo i naslućujemo ponešto od Njegova misterija, a ti su: zbilja, život, misao, ljubav, mudrost, pravda itd. Uviđajući te 
atribute u ograničenim bićima u ograničenom smislu, po načelu znati i ujedno ne znati, pridajemo ih i Punini (Apsolutu, Bogu), no ne kao da bi On bio najveća dobrota, život, pravda i sl., tj. kao onaj najuzvišeniji na ljestvici, dakle, u relativnom smislu, nego u punini. On je sama dobrota, sam život, sama pravda... On nije dio ljestvice, pa makar to bio i njezin najuzvišeniji dio, nego je njezin ontološki temelj i izvor. On je uvjet mogućnosti ljestvice u svakom smislu. No, i tu je potreban izniman oprez da se, govoreći kako se sve savršenosti stvorova nalaze u Apsolutu, ne bi dao dojam kako su one u Njemu kao u nekom predmetu. Potrebno je dakle stalno bdjeti nad onom naravnom sklonosti ljudskog načina spoznaje da stvarnost pretvara u stvari, u objekte. Osim toga i sama analogija, uz redovite nedostatnosti, očituje posebnu slabost kad su u pitanju neke savršenosti koje od ograničenoga idu k neograničenomu; primjerice u Bogu nema savršenosti razuma kao spoznajne moći, u njemu je spoznaja čisti čin. Apsolut je, dakle, čista spoznaja ili čisto mišljenje.

Osim analoškog propinjanja prema misteriju Apsoluta, vrijedno je spomenuti i neke druge srodne putove. Prije svega tu mislimo na simbole: stvorovi su više od puke fotografije, oni su vanjsko vidljivo lice Apsolutova misterija, te su snagom svoje simbolike sposobni upućivati i uzdizati k Misteriju. Tu također treba pridodati i umjetnost, koja je, kao jezik lijepoga, a lijepo je odsjev beskonačnoga, svojevrsna uvoditeljica u misterij Apsoluta.

\section{Zaključak}

Ako naposljetku prihvatimo Brajičićevu postavku da se sve metafizike razlikuju prema stavu koji zauzimaju prema Bogu kao Apsolutnom biću, kao i onu, iako posvojenu ali na vrlo originalan način inkorporiranu u vlastiti sustav, da je zbiljska nenazočnost Misterija u nekom filozofskom sustavu znak njegove upitnosti, uviđamo da upravo pojam misterija može biti jedan od pouzdanih hermeneutičkih ključeva za razlučivanje korijenskih problema u pojedinim filozofskim sustavima. Prihvaćali mi to ili ne, ipak je teško opovrgnuti tezu da svaka filozofija počiva na nekoj metafizici, pa makar i onoj koja tvrdi da je metafizika besmislena; a jedno od ključnih pitanja metafizike, od samih njezinih početaka, jest pitanje odnosa prema onomu što nužno jest. I nije li to upravo ona vječna parmenidovsko-heraklitovska dvojba koja se provlači kroz cijelu povijest filozofije?! U tom smislu smatramo da poimanje Apsoluta kao apsolutnog naravnog misterija može biti ključ za razumijevanje, ali i uravnoteženje radikalnih ontološko-spoznajnih stavova u različitim filozofijama i teologijama. Misterij bi tu osvjetljavao onaj uski ali iznimno važni prolaz između iracionalizma, relativizma, apsurda s jedne strane, te racionalizma, parmenidovskog univerzalizma ili statičkog esencijalizma, s druge strane. Naime, očito je da je misterij neshvatljiv, ali smo također utvrdili da se bit misterija ne sastoji u neshvatljivosti. To prije svega znači da nas njegova neshvatljivost lišava neodržive pretenzije da ćemo ikada moći dohvatiti Puninu i sve o njoj znati: Njegov nutarnji život ostaje nam uvijek zavijen u Njegov misterij, tj. u Njegovu neshvatljivost. Ali to također znači 
da se dijalektikom znati i ujedno ne znati ipak ponešto od Njega, od Njegove punine može naslutiti, barem kao u zrcalu, a onda i smisleno izreći: kad nešto o njemu tvrdimo, znamo što govorimo. To jasno ukazuje na neopravdanost i uzaludnost svakog pokušaja bijega u apsurd relativizma ili iracionalizma, kao i svaka pretenzija za gradnjom filozofskog sustava koji bi objašnjavao totalitet bez ostatka, kao i svaka ideologija koja se postavlja kao supstitut Misteriju, te teologije koja apsolutizira spoznaju Pisma, Tradicije...

The Absolute Always Remains an Absolute Mystery

Anto Pavlović*, Hrvoje Vargić**

\section{Summary}

This article explores the philosophical thought of Rudolf Brajičic with regard to the foundedness and objectivity of synthetic a priori judgements, such that the authors examine the possibility of constituting extended metaphysics, i.e., a metaphysics which expands knowledge and again opens the path to rational theology. The second section examines traditional proofs of God's existence in view of extended metaphysics, while indicating also some new modes of providing proofs. The preceding provides a solid groundwork for the article's basic premise wherewith the authors endeavor to demonstrate that, even after having proven the existence of the Absolute, we still do not have positive deep insight into His essence, into His inner life, and therefore, the Absolute must be understood as an absolute natural mystery, and speech about the Absolute as speech about a mystery.

Key words: Brajičić, extended metaphysics, proving God's existence, Absolute, absolute mystery

* Anto Pavlović, Ph. D., Assistant Professor, The Faculty of Philosophy of the Society of Jesus in Zagreb. Adress: Jordanovac 110, p.p. 169, 10000 Zagreb. E-mail: apavlovic2010@gmail.com

** Hrvoje Vargić, BPhil, The Faculty of Philosophy of the Society of Jesus in Zagreb. Adress: Jordanovac 110, p.p. 169, 10000 Zagreb. E-mail: hrvoje.vargic@gmail.com 